мах продуктивных животных хозяйств ленинградской области / Н.Ю. Югатова, Р.О. Васильев, В.А. Кузьмин, Е.И. и др. // Иппология и ветеринария.- 2018.- № 3 (29).- С. 91-94.

5. Уровни радиоактивного загрязнения воды открытых водоёмов и источников питьевого водоснабжения Волго-Вятского региона Российской Федерации / В.Н. Гапонова, Е.И. Трошин, Р.О.
Васильев, и др. // Международный вестник ветеринарии.- 2019.- № 3.- С. 60-66.

6 . The state of the antioxidant system in cows at different densities of radioactive contamination of the soil / P. Anipchenko, R. Vasiliev, V.Gaponova, [et al.]// The FASEB journal (Federation of American Societies for Experimental Biology).San-Diego.4-7 April 2020.- Vol.34.-Issue S1.- P. 1-1

\title{
RADIATION SAFETY OF FOOD RAW MATERIALS AND FOOD PRODUCTS
}

\author{
V.N. Gaponova \\ (St. Petersburg state University of veterinary medicine)
}

Key words: radiation safety, meat, milk, cesium-137.

Intensive use of radioactive isotopes in industry, abnormal emissions of nuclear fission products into the environment gradually increase the level of natural background radiation. As a result, there is a problem of farming, the main producer of food for the population, raw materials for industry, associated with the control of the level of contamination of soil, water, and livestock products. It is necessary to constantly monitor the radiation situation, namely the content of cesium-137 in soil, water, as well as in animal products both in the North-Western region and in other subjects of the Russian Federation. Due care must be taken when organizing the feeding of productive animals (dairy cows, beef cattle in the final fattening period), whose products, without an additional processing stage, can be directed to consumption by the population.

\section{REFERENCES}

1.Vasiliev R.M. Dynamics of the content of technogenic radionuclides in the objects of veterinary supervision of the NorthWest region / R.M. Vasiliev, V.N. Gaponova // International Bulletin of Veterinary Medicine, 2020.- №4. S. 79-83.

2.. Veterinary and sanitary assessment of products of animal and plant origin in case of radionuclide contamination: study guide. / E.I. Troshin, R.M. Vasiliev, R.O. Vasiliev, V.N. and others - St. Petersburg: SPbGUVM, 2020. - 82 p. 3. Sanitary and microbiological state of waters of small reservoirs of the Leningrad region / P. A. Polistovskaya, K. P. Kinarevskaya, A. A. Bakhta [and others] // Bacteriology. - 2018. - T. 3. - No. 1. - P. 33-35. - DOI 10.20953 / 2500-1027-2018-1-33-35.

4. The content of the main radionuclides in the feed of productive animals of the farms of the Leningrad region / N.Yu. Yugatova, R.O. Vasiliev, V.A. Kuzmin, E.I. et al. // Hippology and Veterinary Medicine. - 2018. - No. 3 (29). - P. 91-94.

5. Levels of radioactive contamination of water in open water bodies and sources of drinking water supply in the Volga-Vyatka region of the Russian Federation / V.N. Gaponova, E.I. Troshin, R.O. Vasiliev, et al. // International Bulletin of Veterinary Medicine. - 2019. - No. 3.- P. 60-66. 6 . The state of the antioxidant system in cows at different densities of radioactive contamination of the soil / P.Anipchenko, R. Vasiliev, V.Gaponova, [et al.]// The FASEB journal (Federation of American Societies for Experimental Biology).San-Diego.- $4-7$ April 2020.Vol.34.-Issue S1.- P. 1-1

DOI: 10.52419/issn2072-6023.2021.4.121

УДК: 614.31:638.165.8

\section{ВЕТЕРИНАРНО-САНИТАРНАЯ ЭКСПЕРТИЗА ЦВЕТОЧНОГО МЁДА}

\author{
Лашкова В.А., Вирич В.Д., Зверева Н.А., Челахова С.А. \\ (ФГБОУ ВО «Санкт-Петербургский университет ветеринарной медицинь»))
}

Ключевые слова: мёд, пчёлы, качество мёда, массовая доля воды, амилазное число, ветеринарно-санитарная экспертиза, ветеринарно-санитарная оценка.

\section{PЕФЕPAT}

Мед - это продукт переработки медоносными пчелами нектара или пади растительного или животного происхождения, представляющий собой сладкое ароматическое вещество или закристаллизованную массу, содержащий значительное количество углеводов, минеральных и биологически активных веществ

В статье представлены результаты ветеринарно-санитарной экспертизы и оценки пяти проб цветочного мёда. Цель исследования: определить качество мёда, полученного с пасек Ленинградской области в соответствии с «Правилами ветеринарно-санитарной экспертизы мёда при продаже на рынках».

Материалами для исследования служили пробы мёда в количестве 100г датой сбора 2020 года. Для проведения исследования определяли органолептические и физико-химические показатели проб мёда. Органолептическую оценку проводили по показателям: цвет, аромат, вкус, консистенция, кристаллизация, определение признаков брожения. Физико-химические показатели: массовая доля воды, присутствие оксиметилфурфурола, диастазная (амилазная) активность, определение общей кислотности.

В результате проведенных органолептических и физико-химических исследований выяснилось, что в пробе №1 - искусственная инверсия мёда и обнаружены отклонения, говорящие о том, что мед не является натуральным. 


\section{ВВЕДЕНИЕ}

Проблема вымирания пчел уже давно стоит перед пасечниками Российской Федерации и всего мира [1]. В связи с этим участились случаи фальсификации мёда и выставления падевого мёда за цветочный. Исходя из этого потребителям важно знать о том подлинный ли состав, приобретенного ими мёда, о его свежесть и годности к употреблению. Цель ветеринарносанитарной экспертизы обеспечить безопасность населения от недоброкачественных продуктов животноводства и растениеводства [3].

Мед - это продукт переработки медоносными пчелами нектара или пади растительного или животного происхождения, представляющий собой сладкое ароматическое вещество или закристаллизованную массу, содержащий значительное количество углеводов, минеральных и биологически активных веществ [2]. В технических целях мёд применяют при изготовлении красок, клея и парфюмерии. Он также обладает бактерицидными свойствами, поэтому применяется для изготовления лекарственных средств.

Исходя из определения, неполноценный мёд представляет собой продукт с естественно или искусственно измененными свойствами. Он может быть фальсифицированным, токсическим или испорченным. В фальсифицированный мёд могут быть добавлены пищевые и кормовые добавки для увеличения его массы. Токсичность и порча мёда бывают естественными - отрицательные органолептические показатели, брожение и закисание; и искусственные - нагревание, механическое загрязнение и ухудшение органолептических показателей в результате нарушения правил гигиены, технологии отбора и хранения мёда, а также недозревший мёд [2].
Цель исследования: определить качество мёда, полученного с пасек Ленинградской области в соответствии с «Правилами ветеринарно-санитарной экспертизы мёда при продаже на рынках».

\section{МАТЕРИАЛЫ И МЕТОДЫ}

Исследования проводились на базе кафедры Ветеринарно-санитарной экспертизы «СанктПетербургского государственного университета ветеринарной медицины». Материалами исследования служили пробы липового, гречишного, лугового, лесного, клеверного меда с пасек Ленинградской области 2020 года сбора.

Всего было отобрано 5 проб меда массой 100г. Пробы незакристаллизованного меда отбирали в соответствии с ГОСТ 19792-2017 с помощью трубчатого пробоотборника, который помещали на всю глубину тары, затем пробоотборник извлекали и сливали в сухой чистый контейнер с крышкой [4].

При органолептической оценке определяли цвет, запах, вкус, консистенцию, кристаллизацию. Из физико-химических показателей определяли: массовую долю воды, общую кислотность, диастазную активность и присутствие оксиметилфурфурола [4]. Органолептические и физикохимические исследования проб меда проводили в соответствии с «Правилами ветеринарно-санитарной экспертизы меда при продаже на рынках».

\section{РЕЗУЛЬТАТЫ И ОБСУЖДЕНИЕ}

В результате органолептических исследований установили, что все пробы меда соответствуют правилам ветеринарно-санитарной экспертизы меда при продаже на рынках.

Все показатели массовой доли воды находятся в допустимых значениях до $21 \%$.

При определение общей кислотности меда было выявлено, что проба №1 имеет отклонение (6,8 градуса при норме от 1 до 4), что говорит об

Таблица 1.

Органолептические показатели меда

\begin{tabular}{|c|c|c|c|c|c|}
\hline $\begin{array}{c}\text { Наименование } \\
\text { показателя }\end{array}$ & $\begin{array}{c}\text { Проба №1 } \\
\text { Липовый мед }\end{array}$ & $\begin{array}{c}\text { Проба №2 } \\
\text { Гречишный мед }\end{array}$ & $\begin{array}{c}\text { Проба №3 } \\
\text { Луговой мед } \\
\end{array}$ & $\begin{array}{l}\text { Проба №4 } \\
\text { Лесной мед }\end{array}$ & $\begin{array}{c}\text { Проба№5 } \\
\text { Клеверный мед }\end{array}$ \\
\hline Цвет & Светло-янтарный & Темно-янтарный & Светло-желтый & $\begin{array}{c}\text { Светло- } \\
\text { коричневый }\end{array}$ & Белый \\
\hline Аромат & $\begin{array}{c}\text { Естественный, } \\
\text { соответствующий } \\
\text { ботаническому } \\
\text { происхождению, } \\
\text { приятный, } \\
\text { сильно выражен- } \\
\text { ный, без } \\
\text { постороннего } \\
\text { запаха } \\
\end{array}$ & $\begin{array}{c}\text { Естественный, } \\
\text { соответствующий } \\
\text { ботаническому } \\
\text { происхождению, } \\
\text { приятный, } \\
\text { сильно выражен- } \\
\text { ный, без } \\
\text { постороннего запа- } \\
\text { ха }\end{array}$ & $\begin{array}{c}\text { Естественный, } \\
\text { соответствующий } \\
\text { ботаническому } \\
\text { происхождению, } \\
\text { приятный } \\
\text { сильно выражен- } \\
\text { ный, без посто- } \\
\text { роннего запаха }\end{array}$ & $\begin{array}{c}\text { Естественный, } \\
\text { соответствующий } \\
\text { ботаническому } \\
\text { происхождению, } \\
\text { приятный } \\
\text { сильно выражен- } \\
\text { ный, без } \\
\text { постороннего за- } \\
\text { паха } \\
\end{array}$ & $\begin{array}{c}\text { Естественный, } \\
\text { соответствующий } \\
\text { ботаническому } \\
\text { происхождению, } \\
\text { приятный } \\
\text { сильно выражен- } \\
\text { ный, без } \\
\text { постороннего } \\
\text { запаха } \\
\end{array}$ \\
\hline Вкус & $\begin{array}{c}\text { Сладкий, прият- } \\
\text { ный, без посто- } \\
\text { ронних привкусов }\end{array}$ & $\begin{array}{c}\text { Сладкий, терпкий, } \\
\text { без посторонних } \\
\text { привкусов }\end{array}$ & $\begin{array}{c}\text { Сладкий, притор- } \\
\text { ный, без посто- } \\
\text { ронних привкусов }\end{array}$ & $\begin{array}{c}\text { Сладкий, прият- } \\
\text { ный, без посторон- } \\
\text { них привкусов }\end{array}$ & $\begin{array}{c}\text { Сладкий, прият- } \\
\text { ный, без посто- } \\
\text { ронних привку- } \\
\text { сов } \\
\end{array}$ \\
\hline Консистенция & Сиропообразная & Плотная & Вязкая & Сиропообразная & Плотная \\
\hline $\begin{array}{c}\text { Кристаллиза- } \\
\text { ция }\end{array}$ & Мелкозернистая & Крупнозернистая & Мелкозернистая & Мелкозернистая & Мелкозернистая \\
\hline
\end{tabular}


Таблица 2.

Физико-химические показатели

\begin{tabular}{|c|c|c|c|c|c|}
\hline Наименование показателя & $\begin{array}{c}\text { Проба №1 } \\
\text { Липовый мед }\end{array}$ & $\begin{array}{c}\text { Проба №2 Гре- } \\
\text { чишный мед }\end{array}$ & $\begin{array}{c}\text { Проба №3 } \\
\text { Луговой мед }\end{array}$ & $\begin{array}{c}\text { Проба №4 } \\
\text { Лесной мед }\end{array}$ & $\begin{array}{c}\text { Проба №5 Кле- } \\
\text { верный мед }\end{array}$ \\
\hline Массовая доля воды, \% & 18,2 & 19 & 17,4 & 18,9 & 17 \\
\hline $\begin{array}{c}\text { Диастазная активность, ед. } \\
\text { Готе }\end{array}$ & 7,0 & 10,0 & 10,0 & 13,9 & 10,0 \\
\hline $\begin{array}{c}\text { Общая кислотность, нор- } \\
\text { мальные градусы }\end{array}$ & 6,8 & 3,3 & 1,2 & 2,5 & 3 \\
\hline $\begin{array}{c}\text { Присутствие } \\
\text { Оксиметилфурфурола }\end{array}$ & «土» & «-» & «-» & «-» & «-» \\
\hline
\end{tabular}

искусственной инверсии меда. В остальных пробах отклонений не обнаружено.

Диастазное число пробы №1 ниже 10 ед. Готе, что может свидетельствовать о нагревании меда.

В пробе №1 качественная реакция на оксиметилфурфурол ложноположительная, следовательно мед скорее всего подвергался термической обработке и не является натуральным. В остальных пробах не обнаружен оксиметилфурфурол, значит мед натуральный.

\section{ЗАКЛЮЧЕНИЕ}

При комплексной оценке органолептических свойств образцов меда, было установлено: все пробы обладали сладким, приятным вкусом и характерным, свойственным меду, ароматом. Без посторонних привкусов, запахов и порочащих оттенков.

При проведении физико-химических исследований выявлено, что пробы №2,3,4,5 полностью удовлетворяют нормативные значения. Проба №1 показала отклонения при определении общей кислотности и диастазного числа, а также присутствие оксиметилфурфурола. Таким образом, основываясь на данные результаты, можно предположить, что липовый мед фальсифицированный.

На основании проведенных исследований мед под образцами №2, 3, 4, 5 соответствует «Правилам ветеринарно-санитарной экспертизы меда при продаже на рынках», обладает рядом характерных органолептических свойств и физико-химических показателей.

\section{ЛИТЕРАТУРА}

1. Беляева, Н.А. Коллапс уверенно шагает по пасекам в Удмуртии / Н.А. Беляева, Н.А. Ледомский, Е.Н. Ледомский // Аграрный вестник Урала. -2009. - № 12. - С. 78-80. 2. Васильев, Д.А. Лабораторный практикум по ветеринарно-санитарной экспертизе меда для студентов факультетов ветеринарной медицины, биотехнологии / Д.А. Васильев, С.В. Мерчина. - Ульяновск: УГСА, 2005. -12 c

3. Позняковский, В.М. Ветеринарно-санитарная экспертиза: учеб. пособие / В.М. Позняковский, М.С. Куракин. Кемеровский технологический институг пищевой промышленности: Кемерово, 2005. - 84 с.

4. Правила ветеринарно-санитарной экспертизы меда при продаже на рынках (угв. Минсельхозпродом РФ 18.07.1995 N 13-7-2/365) (Зарегистрировано в Минюсте РФ 31.08.1995 N 942)

\section{VETERINARY AND SANITARY EXAMINATION OF FLOWER HONEY}

\section{V.A. Lashkova, V.D. Virich, N.A. Zvereva, S.A. Chelakhova \\ (St. Petersburg state university of veterinary medicine)}

Key words: honey, bees, quality of honey, mass fraction of water, amylase number, veterinary-sanitary examination, veterinary-sanitary assessment.

Honey is a product of processing by honey bees of nectar or paddy of vegetable or animal origin, which is a sweet aromatic substance or a crystallized mass containing a significant amount of carbohydrates, mineral and biologically active substances

The article presents the results of veterinary and sanitary examination and evaluation of five samples of flower honey. The purpose of the study: to determine the quality of honey obtained from apiaries of the Leningrad region in accordance with the "Rules of veterinary and sanitary examination of honey for sale in the markets."

The materials for the study were honey samples in the amount of $100 \mathrm{~g}$ with a collection date of 2020 . For the study, the organoleptic and physico-chemical parameters of honey samples were determined. Organoleptic evaluation was carried out according to the following indicators: color, aroma, taste, consistency, crystallization, determination of signs of fermentation. Physico-chemical parameters: mass fraction of water, presence of oxymethylfurfural, diastase (amylase) activity, determination of total acidity.

As a result of organoleptic and physico-chemical studies, it turned out that in sample No. 1 there was an artificial inversion of honey and deviations were found, indicating that honey is not natural.

\section{REFERENCES}

1. Belyaeva, N.A. Collapse confidently walks through apiaries in Udmurtia / N.A. Belyaeva, N.A. Ledomsky, E.N. Ledomsky // Agrarian Bulletin of the Urals. -2009. № 12. - p. 78-80.

2.Vasiliev D.A. Laboratory workshop on veterinary and sanitary examination of honey for students of faculties of veterinary medicine, biotechnology / D.A. Vasiliev, S.V. Merchina. - Ulyanovsk : UGSA, 2005. - 12 p.
3.Poznyakovsky, V.M. Veterinary and sanitary examination: textbook. manual / V.M. Poznyakovsky, M.S. Kurakin. - Kemerovo Technological Institute of Food Industry: Kemerovo, 2005. - 84 p.

4.Rules of veterinary and sanitary examination of honey for sale in the markets (approved by the Ministry of Agriculture and Food of the Russian Federation on 18.07.1995 N 13-7-2/365) (Registered with the Ministry of Justice of the Russian Federation on 31.08.1995 N 942) 